\title{
PENGARUH GAYA KEPEMIMPINAN, PEMANFAATAN TEKNOLOGI INFORMASI, DAN TATA RUANG KANTOR TERHADAP KINERJA PERANGKAT DESA
}

Esti Widyarningsih, Nina Oktarina, Ahmad Saeroji

Jurusan Pendidikan Ekonomi, Fakultas Ekonomi, Universitas Negeri Semarang, Indonesia

\begin{tabular}{|c|c|}
\hline Info Artikel & Abstrak \\
\hline $\begin{array}{l}\text { Sejarah Artikel: } \\
\text { Diterima,19 Januari } 2020 \\
\text { Disetujui, } 12 \text { Maret } 2020 \\
\text { Dipublikasikan, } 30 \text { Juni } 2020\end{array}$ & $\begin{array}{l}\text { Tujuan penelitian ini adalah untuk mengetahui pengaruh gaya kepemimpinan, pemanfaatan teknologi } \\
\text { informasi, dan tata ruang kantor terhadap kinerja perangkat desa Se-Kecamatan Suradadi, Kabupaten Tegal. } \\
\text { Populasi dalam penelitian ini adalah perangkat desa Se-Kecamatan Suradadi dan sampel yang digunakan dalam } \\
\text { penelitian ini sebanyak } 90 \text { orang. Metode pengumpulan data yang digunakan adalah observasi, wawancara, } \\
\text { kuesioner dan dokumentasi. Analisis data menggunakan metode analisis deskriptif persentase, analisis regresi } \\
\text { linear berganda, uji asumsi klasik, dan uji hipotesis dengan bantuan program SPSS For Windows } 21 \text {. Hasil } \\
\text { analisis regresi linear berganda diperoleh persamaan KI }=3,068+0,270 \mathrm{GP}+0,255 \mathrm{PTI}+0,404 \mathrm{TRK}+\mathrm{e} \text {. Hasil } \\
\text { penelitian ini menunjukkan bahwa gaya kepemimpinan, pemanfaatan teknologi informasi, dan tata ruang } \\
\text { kantor secara simultan maupun parsial berpengaruh positif dan signifikan terhadap kinerja perangkat desa Se- } \\
\text { Kecamatan Suradadi Kabupaten Tegal. }\end{array}$ \\
\hline
\end{tabular}
of Information Technology, Office Layout, and Village Officials Performance.

\section{Abstract}

The purpose of this research is to determine the effect of leadership style, utilization of information technology, and office layout on the villageofficials performance in Suradadi Sub-district Tegal Regency. The population in this research was the village officials performance in Suradadi Sub-district Tegal Regency and 90 village officials were analyzed as sample. The methods of data collection were done by observation, interview, questionnaire, and documentation. The methods of data analysis of this research using percentage descriptive analysis, multiple linear regression analysis, the classical assumption test, and hypothesis test with SPSS For Windows 21 program. The equation results of multiple linear regression analysis is $\mathrm{KI}=3.068+0.270 \mathrm{GP}+0.255 \mathrm{PTI}+$ $0.404 \mathrm{TRK}+\mathrm{e}$. The results showed that leadership style, utilization of information technology, and office layout simultaneously or partially have a positive and significant effect on the village officials performance in Suradadi Sub-district Tegal Regency.

\footnotetext{
Alamat korespondensi:

Gedung L3 Lantai 1 FE UNNES

Kampus Sekaran, Gunungpati, Semarang, 50229

E-mail: estiwidyar@gmail.com
} 


\section{PENDAHULUAN}

Setiap organisasi baik organisasi bisnis maupun organisasi pemerintahan, memerlukan sumber daya untuk mencapai tujuannya. Sumber daya manusia merupakan salah satu sumber daya organisai yang memiliki peranan penting dalam mencapai tujuan bersama. Wirawan (2009:1) menjelaskan bahwa "sumber daya manusia merupakan sumber daya yang digunakan untuk menggerakan dan menyinergikan sumber daya lainnya untuk mencapai tujuan organisasi". Namun, kenyataannya sering ditemukan bahwa kemampuan sumber daya manusia belum dapat memenuhi harapan di dalam suatu organisasi. Pembinaan sumber daya manusia adalah menjadi kewajiban seorang manajer atau pemimpin untuk mengembangkan sumber daya manusia di dalam organisasi. Upaya pengembangan sumber daya manusia atau pegawai ini memiliki konsekuensi waktu dan biaya yang harus disediakan seorang pemimpin dan juga organisasi. Namun, hal tersebut diharapkan dapat memberikan manfaat berupa peningkatan kinerja pegawai di dalam suatu organisasi pula.

Pencapaian tujuan organisasi, menuntut pegawai untuk memaksimalkan kinerja yang dia miliki. Mangkunegara (2016:67) menyatakan bahwa kinerja adalah prestasi kerja atau hasil kerja secara kualitas dan kuantitas yang dicapai oleh seorang pegawai dalam melaksanakan tugasnya sesuai dengan tanggung jawab yang diberikan kepadanya. Kinerja pegawai mengacu pada prestasi kerja pegawai diukur berdasarkan standar atau kriteria yang telah ditetapkan oleh suatu organisasi. Wibowo (2016:44) menjelaskan bahwa kinerja bertujuan menyesuaikan harapan kinerja individual dengan tujuan organisasi. Maka dari itu, untuk mencapai tujuan organisasi, tentunya pegawai dituntut untuk memaksimalkan kinerja yang dia miliki. Berdasarkan Undang-Undang Nomor 32 Tahun 2004 tentang Pemerintahan Daerah menyatakan, desa atau yang disebut nama lain adalah kesatuan masyarakat hukum yang memiliki batas wilayah yang berwenang untuk mengatur dan mengurus kepentingan masyarakat setempat, berdasarkan asal usul dan adat istiadat setempat yang diakui dan dihormati dalam sistem pemerintahan negara kesatuan Republik Indonesia.

Kecamatan Suradadi merupakan salah satu kecamatan yang berada di Kabupaten Tegal. Kecamatan Suradadi terdiri dari 11 Desa yang memiliki jumlah pegawai yang berbedabeda yang bertugas untuk mengatur dan mengurus berbagai macam kepentingan masyarakat setempat. Perilaku setiap anggota organisasi dalam melakukan berbagai tugas merupakan sebuah cerminan kinerja pegawai dalam suatu organisasi. Kinerja merupakan hal penting yang harus dicapai oleh setiap instansi termasuk Kantor Balai Desa se-Kecamatan Suradadi, karena kinerja merupakan cerminan bagi kemampuan instansi dalam mengelola dan mengalokasikan pegawainya, oleh karena itu pegawai mempunyai pengaruh yang sangat penting bagi kelangsungan kegiatan instansi dan bagi proses pencapaian tujuan suatu organisasi.

Sudarmanto (2009:7) menjelaskan bahwa faktor-faktor yang mempengaruhi kinerja yaitu faktor internal pegawai, faktor lingkungan internal organisasi, dan faktor lingkungan eksternal organisasi. Faktor internal pegawai merupakan faktor dari dalam diri pegawai yang merupakan bawaan dari lahir misalnya bakat, sifat pribadi atau karakteristik seseorang, keadaan fisik, keadaan fisik, keadaan jiwa, dan faktor yang diperoleh ketika seorang individu berkembang semasa hidupnya misalnya pengetahuan, keterampilan, pengalaman kerja, dan motivasi. Faktor lingkungan internal organisasi dalam melaksanakan tugasnya adalah seorang pegawai memerlukan dukungan organisasi tempat seseorang bekerja, dukungan tersebut akan sangat mempengaruhi kinerja pegawai misalnya strategi organisasi, dukungan sumber daya manusia yang diperlukan untuk bekerja, sistem manajemen yang ada di dalam organisasi, dan kompensasi. Faktor lingkungan eksternal organisasi merupakan suatu keadaan atau situasi yang terjadi diluar lingkungan organisasi yang mempengaruhi kinerja misalnya kurs rupiah dan budaya masyarakat.

Setiap desa memiliki seorang pemimpin yang disebut dengan kepala desa. Peranan kepala desa terhadap peningkatan kinerja para 
pegawai di kelurahan dan keberhasilan pencapaian tujuan suatu organisasi sangatlah penting. Wibowo (2016:69) yang menjelaskan bahwa gaya kepemimpinan dalam organisasi sangat berperan dalam mempengaruhi kinerja karyawan, bagaimana pemimpin menjalin hubungan dengan pekerja, bagaimana mereka memberi penghargaan kepada pekerja yang berprestasi, bagaimana mereka mengembangkan dan memberdayakan pekerjaannya, sangat mempengaruhi kinerja sumber daya manusia yang menjadi bawahannya.

Usaha untuk meningkatkan kinerja pegawai dalam menyelesaikan pekerjaan dan tanggung jawabnya perlu adanya dukungan dari seorang pemimpin. Keberhasilan suatu organisasi dapat dipersepsikan sebagai keberhasilan dari seorang pemimpin. Dengan adanya seorang pemimpin yang memiliki gaya kepemimpinan yang baik, maka akan dapat mempengaruhi kinerja pegawainya. Hal tersebut nantinya juga akan berpengaruh pada pencapaian efektivitas yang optimal karena gaya kepemimpinan pada hakekatnya mengandung pengertian bagaimana seorang pemimpin berhadapan dengan bawahannya agar dapat menciptakan keteraturan dan keselarasan di dalam suatu organisasi.

Gaya kepemimpinan merupakan perilaku atau cara yang dipilih dan dipergunakan seorang pemimpin dalam mempengaruhi pikiran, perasaan, sikap dan perilaku para anggota organisasi bawahannya. Rivai (2006:84) menyatakan bahwa gaya kepemimpinan merupakan perilaku dan strategi, sebagai hasil kombinasi dari falsafah, keterampilan, sifat, sikap yang sering diterapkan seorang pemimpin ketika ia mencoba mempengaruhi kinerja bawahannya. Griffin (1990:475) menjelaskan bahwa "Leadership can be define as either a process or a property. As a process, leadership is the use of noncoercive influence to shape the group's or organisationz's goals, and help define group or organization culture. As a property, leadership is the set of characteristics attributed to individuals who are perceived to be leaders". Artinya kepemimpinan dapat diartikan sebagai proses sekaligus atribut. Sebagai proses, kepemimpinan adalah penggunaan pengaruh tanpa paksaan untuk membentuk tujuan-tujuan grup atau organisasi, dan membantu mendefinisikan kultur grup atau organisasi. Sebagai atribut, kepemimpinan adalah sekelompok karakteristik yang dimiliki oleh seorang individu yang dipandang sebagai pemimpin (Griffin, 2002:68).

Dukungan melalui gaya kepemimpian yang baik, maka pimpinan akan dapat mempengaruhi pegawai untuk mencapai tujuan organisasi yang diinginkan. Hal ini sejalan dengan pendapat Griffin (2002:69) yang menyatakan bahwa kepemimpinan diperlukan untuk menciptakan perubahan, dan manajemen yang diperlukan untuk menciptakan keteraturan. Sehingga perlu adanya dukungan dari kepala desa melalui gaya kepemimpian yang baik agar dapat mempengaruhi pegawai untuk mencapai tujuan organisasi yang diinginkan. Hal ini juga senada dengan penelitian Iqbal (2015) menunjukkan bahwa gaya kepemimpinan berpengaruh positif terhadap kinerja pegawai di instansi tersebut.

Berbagai aspek kehidupan manusia telah dipengaruhi oleh perkembangan teknologi yang akhirnya cara hidup dan bekerja masyarakat berubah ke arah pemanfaatan teknologi informasi. Perkembangan teknologi telah merambah ke berbagai bidang kehidupan manusia dan tidak dapat dipungkiri bahwa teknologi dapat meningkatkan efektivitas dan efisiensi kerja pegawai.

Pemanfaatan teknologi informasi sudah seharusnya digunakan secara tepat dan bijak sehingga apa yang menjadi tujuan dari suatu organisasi dapat tercapai secara efektif dan efisien. Dengan adanya dukungan dari pemanfaatan teknologi informasi yang berada di dalam suatu organisasi, maka kinerja pegawai juga dapat meningkat. Hal ini senada dengan pendapat Simarmata (2006:3) yang menyatakan bahwa teknologi bertujuan memfasilitasi ikhtiar manusia (human endeavor) sehingga harus mampu meningkatkan performa kemampuan manusia. Hal ini senada dengan hasil penelitian yang Muzakki, dkk (2016) menunjukkan bahwa penggunaan teknologi informasi berpengaruh terhadap kinerja pegawai di perusahaan tersebut. Tata ruang kantor juga dapat 
menunjang pekerjaan pegawai di dalam suatu organisasi.

Selain gaya kepemimpinan dan pemanfaatan teknologi informasi, tata ruang kantor juga dapat menunjang penyelesaian pekerjaan seorang pegawai di dalam suatu organisasi. Sukoco (2007:189) menyatakan bahwa tujuan penataan layout kantor selain memperlancar pekerjaan juga menciptakan rasa nyaman, aman bagi pegawai, memberikan kesan baik kepada tamu, dan mencegah efisiensi tenaga dan waktu pegawai bekerja. Upaya untuk mencapai kesan yang nyaman pada setiap individu, diharapkan dapat meningkatkan kinerja yakni dalam meyelesaikan pekerjaan yang menjadi tanggung jawab mereka. Sedarmayanti (2001:126) juga menyatakan bahwa tujuan dari tata ruang kantor yaitu mencegah penghamburan tenaga dan waktu para pegawai karena prosedur kerja dapat dipersingkat, memungkinkan pemakaian ruang kerja secara efisien serta menjamin kelancaran proses pekerjaan yang bersangkutan.

Tujuan penelitian adalah untuk menganalisis pengaruh gaya kepemimpinan, pemanfaatan teknologi informasi dan tata ruang kantor terhadap kinerja perangkat desa (Studi pada Perangkat Desa Se-Kecamatan Suradadi Kabupaten Tegal)".

\section{METODE}

Metode yang digunakan dalam penelitian ini adalah metode kuantitatif dengan desain kausalitas. Lokasi penelitian dilakukan di Kantor Balai Desa Se-Kecamatan Suradadi, Kabupaten Tegal. Desain yang digunakan dalam penelitian ini merupakan desain penelitian kausalitas. Populasi dalam penelitian ini adalah seluruh pegawai Kantor Balai Desa sejumlah 116 perangkat desa terkecuali Kepala Desa karena dalam penelitian ini terdapat variabel yang mengukur gaya kepemimpinan kepala desa. Metode pengumpulan data yang digunakan adalah wawancara, angket, observasi, dan dokumentasi. Teknik analisis data menggunakan analisis deskriptif persentase, analisis regresi linear berganda.

\section{HASIL DAN PEMBAHASAN}

Analisis deskriptif presentase diperoleh hasil yaitu variable gaya kepemimpinan memiliki rata-rata sebesar $80 \%$ dan termasuk ke dalam kriteria baik. Variabel pemanfaatan teknologi informasi memiliki rata-rata sebesar $80 \%$ dan termasuk ke dalam kriteria baik. Kemudian variable tata ruang kantor memiliki rata-rata sebesar $79 \%$ dan termasuk ke dalam kriteria baik.

Tabel 1. Hasil Uji Kolmogorov-Smirnov

One-Sample Kolmogorov-Smirnov Test

\begin{tabular}{llr}
\hline & & \multicolumn{2}{c}{ Unstandardized } \\
& & 90 \\
$\mathrm{~N}$ & & .0000000 \\
Normal & Mean & 2.66197190 \\
Parameters & Std. & \\
a,b & Deviation & .090 \\
Most & Absolute & .071 \\
Extreme & Positive & -.090 \\
Differences & Negative & .851 \\
Kolmogorov-Smirnov & .464 \\
Z & \\
Asymp. Sig. (2-tailed) & \\
\hline a. Test distribution is Normal. \\
\hline b. Calculated from data. \\
\hline Sumber: Data primer diolah, 2019
\end{tabular}


Tabel 2. Hasil Analisis Regresi Linier Berganda

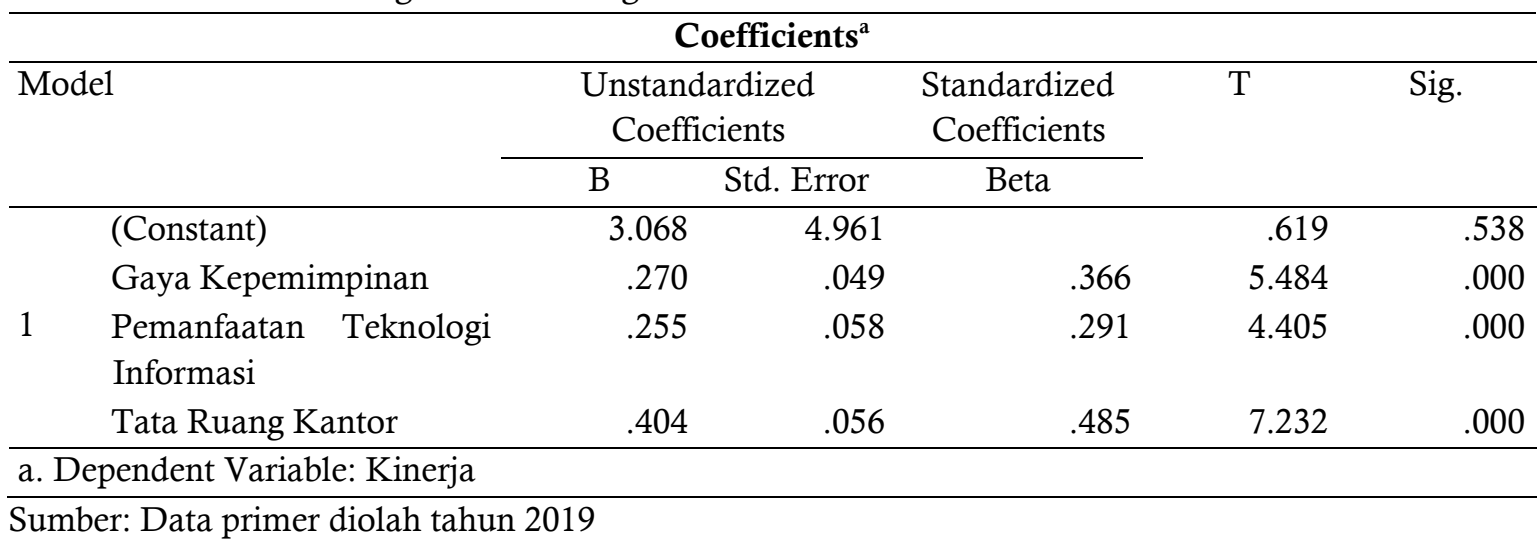

Berdasarkan hasil penelitian, menunjukkan persamaan regresi yang diperoleh dari hasil analisis regresi linear berganda yaitu $\mathrm{KI}=3,068+0,270 \mathrm{GP}+0,255 \mathrm{PTI}+0,404 \mathrm{TRK}$ + e. Nilai koefisien pada setiap variabel bebas memiliki nilai positif yaitu untuk variabel gaya kepemimpinan sebesar 0,270 , hal ini berarti jika gaya kepemimpinan mengalami peningkatan satu satuan dan variabel lainnya bernilai tetap, maka variabel kinerja pegawai akan mengalami peningkatan sebesar 0,270. Variabel pemanfaatan teknologi informasi sebesar 0,255, hal ini berarti jika pemanfaatan teknologi informasi mengalami peningkatan satu satuan dan variabel lainnya bernilai tetap, maka variabel kinerja pegawai akan mengalami peningkatan sebesar 0,255 .

Variabel tata ruang kantor sebesar 0,404, hal ini berarti jika tata ruang kantor mengalami peningkatan satu satuan dan variabel lainnya bernilai tetap, maka variabel kinerja pegawai akan mengalami peningkatan sebesar 0,404. Sedangkan untuk nilai konstanta yaitu 3,068. Diperolehnya koefisien positif pada setiap variabel bebas menunjukkan bahwa variabel gaya kepemimpinan, pemanfaatan teknologi informasi, dan tata ruang kantor mempunyai pengaruh positif terhadap kinerja perangkat desa di Kantor Balai Desa Se-Kecamatan Suradadi Kabupaten Tegal. Merujuk hasil regresi di atas bahwa variabel tata ruang kantor memiliki pengaruh yang paling besar terhadap kinerja perangkat desa diantara variabel yang lain yaitu sebesar 0,404 .

Variabel tata ruang kantor memiliki pengaruh yang besar yaitu sebesar 0,404 dikarenakan berdasarkan hasil pengamatan pada tanggal 6 sampai 14 Desember 2018 menunjukkan bahwa kantor balai desa sudah menerapkan asas-asas tata ruang kantor diantaranya adalah asas jarak terpendek, rangkaian kerja, dan penggunaan segenap ruangan. Hal tersebut dibuktikan dengan tempat kerja pegawai dan penempatan alat-alat diletakan dalam jarak yang dekat, kemudian alat-alat kantor yang akan digunakan sejalan dengan urutan-urutan penyelesaian pekerjaan kantor dari pegawai yang bersangkutan contohnya satu komputer bergandengan dengan satu printer. Selain itu, ruangan di kantor balai desa juga dipergunakan sepenuhnya sehingga tidak ada ruangan yang kosong dan memiliki ruangan yang mudah diubah atau disusun kembali. Hal ini menunjukkan bahwa kantor balai desa se-Kecamatan Suradadi memiliki tata ruang kantor yang baik karena sudah menerapkan asas-asas tata ruang kantor.

Menurut Sedarmayanti (2001:125) "tujuan pengaturan tata ruang yang baik akan mengakibatkan pelaksanaan pekerjaan kantor dapat diatur secara tertib dan lancar. Dengan demikian komunikasi kerja pegawai akan semakin lancar, sehingga koordinasi dan pengawasan semakin mudah serta akhirnya dapat mencapai efisiensi kerja". Sebaliknya pada variabel pemanfaatan teknologi informasi yang memiliki pengaruh paling rendah yaitu sebesar 0,255 dikarenakan berdasarkan hasil pengamatan pada tanggal 6 sampai 14 Desember 2018, hal ini terjadi karena dalam setiap kantor balai desa hanya terdapat 1 sampai 3 pegawai yang dapat menggunakan teknologi 
informasi seperti komputer, sehingga terkadang harus meminta bantuan dari pegawai lain untuk menyelesaikan tugasnya.

Kadir (2005:10) menyatakan bahwa pemakai merupakan komponen penentu keberhasilan penerapan teknologi informasi". Sumber daya manusia atau pegawai yang belum memiliki kemampuan yang memadai dalam menggunakan teknologi informasi, maka akan dapat mempengaruhi pencapaian tujuan baik tujuan organisasi maupun tujuan perseorangan.
Hal ini senada dengan pendapat Kadir (2005:22) yang menyatakan bahwa "peranan teknologi informasi pada masa sekarang tidak hanya diperuntukkan bagi organisasi, melainkan juga untuk kebutuhan perseorangan". Mengingat betapa pentingnya pemanfaatan teknologi informasi, maka penggunaan teknologi informasi harus ditingkatkan lagi dan didukung dengan kemampuan sumber daya manusia yang ada di dalam suatu organisasi. Hasil analisis uji Simultan F dapat dilihat pada tabel berikut ini:

Tabel 3. Hasil Analisis Uji F (Secara Simultan)

\begin{tabular}{|c|c|c|c|c|c|c|}
\hline \multicolumn{7}{|c|}{ ANOVA $^{\mathrm{a}}$} \\
\hline Model & & Sum of Squares & Df & $\begin{array}{l}\text { Mean } \\
\text { Square }\end{array}$ & $\mathrm{F}$ & Sig. \\
\hline \multirow{3}{*}{1} & Regression & 1175.293 & 3 & 391.764 & 53.423 & $.000^{\mathrm{b}}$ \\
\hline & Residual & 630.662 & 86 & 7.333 & & \\
\hline & Total & 1805.956 & 89 & & & \\
\hline
\end{tabular}

a. Dependent Variable: Kinerja

b. Predictors: (Constant), Tata Ruang Kantor, Pemanfaatan Teknologi Informasi, Gaya Kepemimpinan

Sumber : Data primer diolah tahun 2019

Dari hasil perhitungan uji simultan $\mathrm{F}$ dengan menggunakan SPSS for Windows Release 21,0 dapat diketahui bahwa $\mathrm{F}_{\text {hitung }}=53,423$ dengan nilai signifikansi sebesar $0,000<0,05$, ini berarti $\mathrm{Ha}$ diterima. Maka $\mathrm{H}_{1}$ yang menyatakan bahwa terdapat pengaruh yang signifikan dari gaya kepemimpinan, pemanfaatan teknologi informasi dan tata ruang kantor terhadap kinerja perangkat desa di Kantor Balai Desa se-Kecamatan Suradadi diterima. Hal ini senada dengan hasil penelitian yang dilakukan oleh
Anasari dan Suryani (2015) menyatakan bahwa kepemimpinan, lingkungan kerja, dan fasilitas kantor berpengaruh positif dan signifikan secara simultan terhadap kinerja perangkat desa di instansi tersebut. Selain itu, penelitian yang dilakukan oleh Ardilla dan Pramusinto (2015) juga menunjukkan bahwa kepemimpinan, komunikasi internal, dan motivasi kerja terhadap kinerja pegawai di instansi tersebut. Hasil analisis uji parsial $t$ dapat dilihat pada tabel Coefficient sebagai berikut:

Tabel 4. Hasil Analisis Uji t (Secara Parsial)

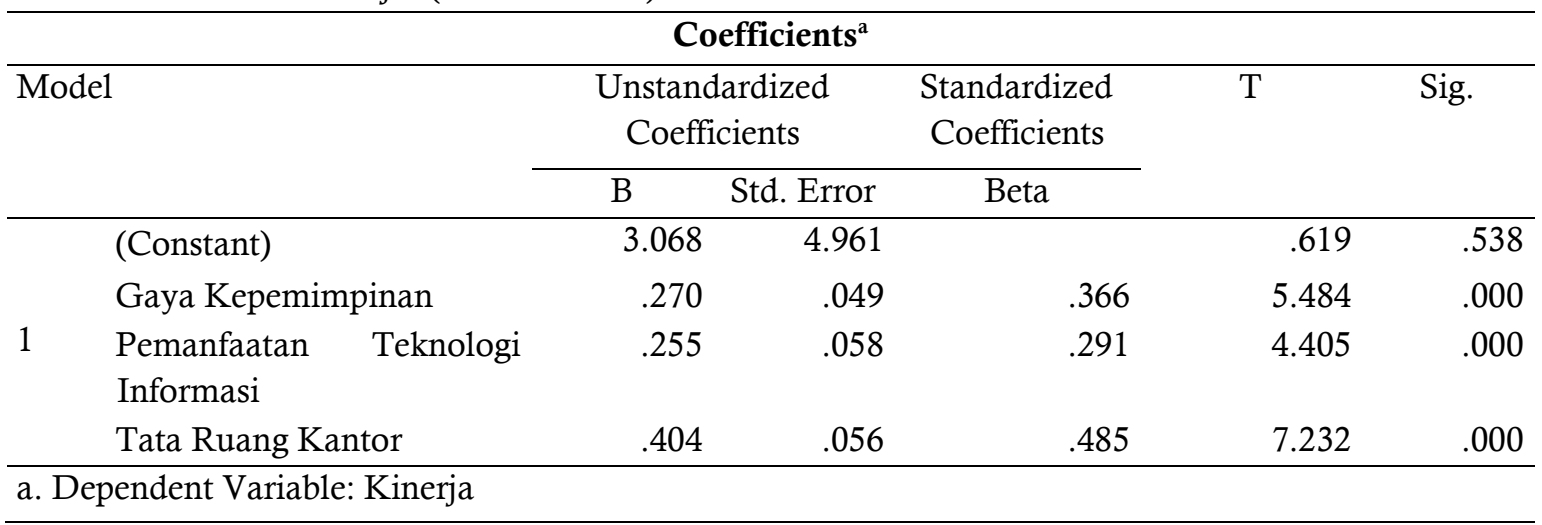

Sumber : Data primer diolah tahun 2019 
Dari hasil pengujian statistik parsial $\mathrm{t}$ dengan menggunakan SPSS for Windows Release 21,0 dapat diketahui bahwa pada variabel gaya kepemimpinan diperoleh $\mathrm{t}_{\text {hitung }}=5,484$ dan sig $=$ $0,000<0,05$. Nilai tersebut menunjukkan $t_{\text {hitung }}$ berpengaruh positif dan signifikan, ini berarti Ha diterima. Maka $\mathrm{H}_{2}$ yang menyatakan bahwa terdapat pengaruh yang signifikan dari gaya kepemimpinan terhadap kinerja perangkat desa di Kantor Balai Desa se-Kecamatan Suradadi diterima. Hal tersebut bermakna bahwa pengaruh gaya kepemimpinan dapat meningkatkan kinerja perangkat desa di Kantor Balai Desa se-Kecamatan Suradadi diterima.

Hal ini senada dengan pendapat Wibowo (2016:69) yang menjelaskan bahwa gaya kepemimpinan dalam organisasi sangat berperan dalam mempengaruhi kinerja karyawan, bagaimana pemimpin menjalin hubungan dengan pekerja, bagaimana mereka memberi penghargaan kepada pekerja yang berprestasi, bagaimana mereka mengembangkan dan memberdayakan pekerjaannya, sangat mempengaruhi kinerja sumber daya manusia yang menjadi bawahannya. Selain itu, nilai thitung yang bernilai positif terhadap kinerja perangkat desa menandakan bahwa semakin baik gaya kepemimpinan maka kinerja perangkat desa desa di Kantor Balai Desa se-Kecamatan Suradadi juga akan semakin baik. Pendapat tersebut juga didukung dengan hasil penelitian Mamik (2010) bahwa gaya kepemimpinan, motivasi kerja, dan komitmen kerja berpengaruh terhadap kinerja pegawai.

Variabel pemanfaatan teknologi informasi diperoleh $t_{\text {hitung }}=4,405$ dan sig $=$ $0,000<0,05$. Nilai tersebut menunjukkan $t_{\text {hitung }}$ berpengaruh positif dan signifikan, ini berarti $\mathrm{Ha}$ diterima. Maka $\mathrm{H}_{3}$ yang menyatakan terdapat pengaruh yang signifikan dari pemanfaatan teknologi informasi terhadap kinerja perangkat desa di Kantor Balai Desa seKecamatan Suradadi diterima. Hal tersebut bermakna bahwa pengaruh pemanfaatan teknologi dapat meningkatkan kinerja perangkat desa di Kantor Balai Desa se-Kecamatan Suradadi diterima. Hal ini senada dengan pendapat Simarmata (2006:3) yang menyatakan bahwa teknologi bertujuan memfasilitasi ikhtiar manusia (human endeavor) sehingga harus mampu meningkatkan performa kemampuan manusia.

Selain itu, nilai $t_{\text {hitung }}$ yang positif terhadap kinerja perangkat desa menandakan bahwa semakin optimal pemanfaatan teknologi informasi maka kinerja perangkat desa desa di Kantor Balai Desa se-Kecamatan Suradadi juga akan semakin baik. Hal ini didukung dengan hasil penelitian Fitriani (2018) yang menunjukkan bahwa penggunaan teknologi informasi berpengaruh positif dan signifikan terhadap kinerja karyawan di instansi tersebut.Variabel tata ruang kantor diperoleh $\mathrm{t}_{\text {hitung }}=7,232$ dan sig $=0,000<0,05$. Nilai tersebut menunjukkan $t_{\text {hitung }}$ berpengaruh positif dan signifikan, ini berarti $\mathrm{Ha}$ diterima. Maka $\mathrm{H}_{4}$ yang menyatakan bahwa terdapat pengaruh yang signifikan dari tata ruang kantor terhadap kinerja perangkat desa di Kantor Balai Desa seKecamatan Suradadi Kabupaten Tegal diterima. Hal tersebut bermakna bahwa pengaruh tata ruang kantor dapat meningkatkan kinerja perangkat desa di Kantor Balai Desa seKecamatan Suradadi Kabupaten Tegal diterima.

Hal ini senada dengan pendapat Gavinov (2016:43) yang menyatakan bahwa tujuan tata ruang kantor yaitu memberikan kenyamanan kepada karyawan, memudahkan dalam pemberian pelayanan, manfaatkan ruangan kantor dengan maksimal, sehingga tidak ada ruang yang tidak berguna, memudahkan arus komunikasi dan arus kerja, , memudahkan gerak karyawan dalam bekerja, menjauhkan dari kebisingan yang terjadi, dan memberikan pencitraan yang baik kepada pelanggan maupun tamu perusahaan. Selain itu, nilai thitung yang positif terhadap kinerja perangkat desa menandakan bahwa semakin mendukung tata ruang kantor maka kinerja perangkat desa desa di Kantor Balai Desa se-Kecamatan Suradadi Kabupaten Tegal juga akan semakin baik. Hal ini juga senada dengan hasil penelitian yang dilakukan oleh Palupi dan Rustiana (2014) yang menunjukkan bahwa tata ruang kantor, fasilitas kantor, dan motivasi kerja berpengaruh positif dan signifikan terhadap kinerja karyawan di instansi tersebut. 
Esti, Nina, Ahmad/ Business and Accounting Education Journal 1 (1) (2020)

Hasil uji koefisien determinasi simultan

$\left(\mathrm{R}^{2}\right)$ dapat dilihat pada tabel berikut ini

Tabel 5. Hasil Uji Koefisien Determinasi Simultan $\left(\mathrm{R}^{2}\right)$

\begin{tabular}{|c|c|c|c|}
\hline \multicolumn{4}{|c|}{ Model Summary ${ }^{b}$} \\
\hline Model & R Square & Adjusted R Square & $\begin{array}{l}\text { Std. Error of the } \\
\text { Estimate }\end{array}$ \\
\hline 1 & $.807^{\mathrm{a}}$ & .639 & 2.708 \\
\hline $\begin{array}{l}\text { a. Predictors: } \\
\text { Kepemimpinan }\end{array}$ & (Constant), Tata Ruang Kantor, & Pemanfaatan Teknolog & i Informasi, Gaya \\
\hline
\end{tabular}

Sumber: Data primer diolah, 2019

Berdasarkan tabel hasil uji koefisen determinasi simultan diatas dapat dilihat pada Adjusted $R$ Square sebesar 0,639. Nilai Adjusted $R$ Square tersebut dikalikan $100 \%$ untuk dapat mengetahui besarnya nilai $\mathrm{R}^{2}$ yakni sebesar $63,9 \%$. Hal ini menunjukkan bahwa gaya kepemimpinan, pemanfaatan teknologi, dan tata ruang kantor secara bersama-sama berpengaruh terhadap kinerja perangkat desa Se-Kecamatan Suradadi Kabupaten Tegal sebesar $63,9 \%$ dan sisanya yaitu sebesar $36,1 \%$ dan sisanya

dijelaskan oleh faktor lain yang tidak dikaji pada penelitian ini. Hal ini Hasil determinasi simultan ini jika dilakukan uji secara simultan hasilnya akan lebih besar jika dibandingkan total dari uji parsial. Hal tersebut dikarenakan pada uji simultan atar variabel memiliki hubungan kerjasama yang membentuk simbiosis mutualisme sehingga jika ditingkatkan secara bersama-sama maka hasilnya akan lebih besar. Sedangkan besar nilai determinasi secara parsial dijelaskan pada tabel berikut:

Tabel 6. Hasil Uji Koefisien Determinasi Secara Parsial $\left(\mathrm{r}^{2}\right)$

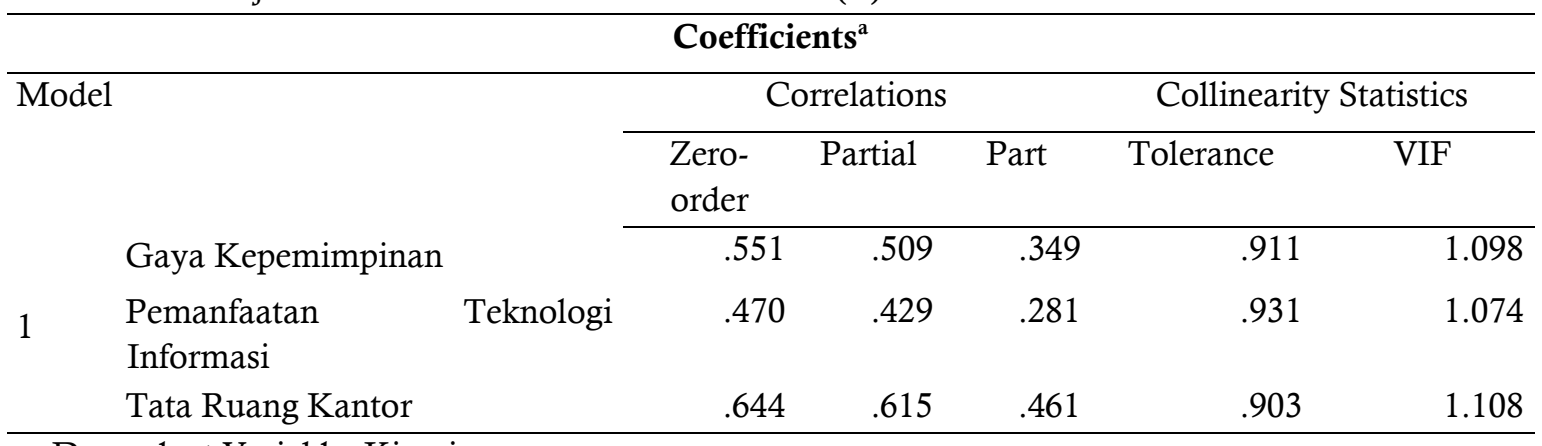

a. Dependent Variable: Kinerja

Sumber: Data primer diolah, 2019

Berdasarkan tabel diatas, pengujian hipotesis pada $\mathrm{H}_{\mathrm{a} 2}$ yang menyatakan bahwa gaya kepemimpinan secara parsial berpengaruh positif dan signifikan terhadap kinerja perangkat desa diterima. Hal ini ditunjukkan dengan hasil regresi besarnya $t_{\text {hitung }}$ sebesar 5,484 dengan signifikansi $0,000<0,005$. Sedangkan besarnya kontribusi variabel gaya kepemimpinan terhadap kinerja perangkat desa adalah $(0,509)^{2}$ $\mathrm{x} 100 \%=25,9 \%$. Gaya kepemimpinan yang cukup baik dapat menjelaskan kinerja perangkat desa. Dengan demikian dapat disimpulkan bahwa semakin baik gaya kepemimpinan yang dimiliki oleh kepala desa maka semakin tinggi pula kinerja perangkat desa di Kantor Balai Desa Se-Kecamatan Suradadi Kabupaten Tegal.

Berdasarkan hasil analisis deskriptif persentase mengenai gaya kepemimpinan menunjukkan bahwa rata-rata gaya kepemimpinan kepala desa masuk dalam keriteria baik yaitu dengan persentase sebesar $80 \%$. Persentase skor terendah yaitu indikator kepemimpinan yang berotientasi pada prestasi sebesar $77 \%$, ditunjukkan dengan item pernyataan nomor 28 "pimpinan mendorong saya untuk dapat mengerjakan tugas yang diberikan dengan baik dan benar", pernyataan 
tersebut memiliki jumlah skor 334. Hal ini menunjukkan bahwa masih ada kepala desa yang belum memberikan dorongan kepada perangkat desa untuk mengerkan tugas dengan baik dan benar. Hal ini sesuai dengan hasil wawancara yang telah dilakukan dengan Bapak Umar Khasan pada tanggal 6 Desember 2018 , bahwa masih ada kepala desa yang kurang baik dalam memimpin contohnya dalam memberikan motivasi atau dorongan kepada perangkat desa dalam melakukan suatu pekerjaan.

Kartono (2009:88) menyatakan bahwa "kepemimpinan ialah satu bentuk dominasi yang didasari oleh kapasitas/kemampuan pribadi, yaitu mampu mendorong dan mengajak orang lain untuk berbuat sesuatu guna mencapai tujuan bersama." Pemimpin yang baik memiliki kemampuan untuk mempengaruhi dan mendorong bawahannya agar dapat mengerjakan tugas sesuai dengan yang telah ditentukan organisasi. Pendapat tersebut juga didukung dengan hasil penelitian Puspitasari dan Oktarina (2018) menunjukkan bahwa gaya kepemimpinan mempunyai pengaruh yang positif dan signifikan terhadap kinerja pegawai di Dinas Sosial, Pemberdayaan Perempuan, dan Perlindungan Anak (DinsosP2PA) Kabupaten Demak. Pengujian hipotesis pada $\mathrm{H}_{\mathrm{a} 3}$ yang menyatakan bahwa pemanfaatan teknologi informasi secara parsial berpengaruh positif dan signifikan terhadap kinerja perangkat desa diterima.

Hal ini ditunjukkan dengan hasil regresi besarnya $t_{\text {hitung }}$ sebesar 4,405 dengan signifikansi $0,000<0,005$. Sedangkan besarnya kontribusi variabel pemanfaatan teknologi informasi terhadap kinerja perangkat desa adalah $(0,429)^{2}$ $\mathrm{x} 100 \%=18,4 \%$. Pemanfaatan teknologi informasi yang cukup optimal dapat menjelaskan kinerja perangkat desa. Dengan demikian dapat disimpulkan bahwa semakin optimal pemanfaatan teknologi informasi maka semakin tinggi pula kinerja perangkat desa, sebaliknya semakin tidak optimal pemanfaatan teknologi informasi maka semakin rendah pula kinerja perangkat desa di Kantor Balai Desa SeKecamatan Suradadi Kabupaten Tegal. Berdasarkan hasil analisis deskriptif persentase mengenai pemanfaatan teknologi informasi menunjukkan bahwa rata-rata pemanfaatan teknologi informasi masuk dalam keriteria baik yaitu dengan persentasae sebesar $80 \%$. Persentase skor terendah yaitu indikator penggunaan informasi sebesar $79 \%$, ditunjukkan dengan item pernyataan nomor 37 "informasi data yang didapatkan dari komputer, mudah untuk dimengerti", pernyataan tersebut memiliki jumlah skor 352 .

Hal ini menunjukkan bahwa masih ada perangkat desa yang sulit untuk memahami informasi data yang diperoleh dari komputer. Hal ini sesuai dengan hasil wawancara yang telah dilakukan, bahwa masih ada perangkat desa yang tidak dapat menggunakan teknologi informasi sehingga sulit memahami informasi data yang ada di komputer. Pada dasarnya teknologi informasi merupakan seperangkat alat yang membantu seseorang bekerja dengan informasi dan melaksanakan tugas-tugas yang berhubungan dengan pemrosesan informasi. Maka dari itu, dengan adanya pemanfaatan teknologi informasi yang optimal dan pemahaman informasi data yang didapatkan dari komputer akan dapat membantu seseorang menyelesaikan pekerjaannya.

Simarmata (2006:3) menyatakan bahwa "teknologi bertujuan memfasilitasi ikhtiar manusia (human endeavor) sehingga harus mampu meningkatkan performa kemampuan manusia". Dengan demikian, pemanfaatan teknologi informasi yang optimal di suatu organisasi akan dapat membantu menyelesaikan pekerjaannya dan dapat mempengaruhi kinerja pegawainya. Pendapat tersebut juga didukung dengan hasil penelitian Muzakki, dkk (2016) yang menunjukkan bahwa pemanfaatan teknologi informasi berpengaruh positif dan signifikan terhadap kinerja karyawan di PT. Telkom Pusat Divisi Regional V Surabaya. Pengujian hipotesis pada $\mathrm{H}_{\mathrm{a} 4}$ yang menyatakan bahwa tata ruang kantor secara parsial berpengaruh positif dan signifikan terhadap kinerja perangkat desa diterima. Hal ini ditunjukkan dengan hasil regresi besarnya $t_{\text {hitung }}$ sebesar 7,232 dengan signifikansi 0,000 < 0,005. Sedangkan besarnya kontribusi variabel tata ruang kantor terhadap kinerja perangkat desa adalah $(0,615)^{2} \times 100 \%=37,8 \%$. tata ruang 
kantor yang cukup mendukung dapat menjelaskan kinerja perangkat desa.

Dengan demikian dapat dikatakan bahwa semakin mendukung tata ruang kantor yang ada di suatu organisasi maka semakin tinggi pula kinerja perangkat desa, sebalikya bahwa semakin tidak mendukung tata ruang kantor yang ada di suatu organisasi maka semakin rendah pula kinerja perangkat desa di Kantor Balai Desa Se-Kecamatan Suradadi Kabupaten Tegal.

Berdasarkan hasil analisis deskriptif persentase mengenai tata ruang kantor menunjukkan bahwa rata-rata tata ruang kantor masuk dalam keriteria mendukung yaitu dengan persentasae sebesar 79\%. Persentase skor terendah yaitu indikator penyusunan perabot sebesar $77 \%$, ditunjukkan dengan item pernyataan nomor 57 "alat pengatur udara (AC/kipas angin) di dalam ruangan berfungsi dengan baik", pernyataan tersebut memiliki jumlah skor 324. Hal ini menunjukkan bahwa masih ada persyaratan lingkungan fisik seperti alat pengatur udara di dalam ruangan yang belum memberikan kenyamanan bagi perangkat desa dalam mengerjakan tugas dan pekerjaannya.

Hal ini sesuai dengan hasil wawancara yang telah dilakukan, bahwa masih ada alat pengatur udara (kipas angin) di dalam ruangan yang sudah tidak berfungsi dan dibiarkan begitu saja. Berdasarkan hasil pengamatan yang telah saya lakukan dari tanggal 6 sampai 14 Desember 2018 ditemukan bahwa masih terdapat kantor balai desa yang tidak memiliki alat pengatur udara. 3 dari 11 kantor balai desa memiliki kipas angin tetapi sudah tidak berfungsi dan 4 dari 11 kantor balai desa tidak memiliki alat pengatur udara seperti AC atau kipas angin. Hal ini sesuai dengan hasil wawancara yang telah dilakukan, bahwa masih ada alat pengatur udara (kipas angin) di dalam ruangan yang sudah tidak berfungsi.

Pengaturan dan penyusunan perabot, alat perlengkapan kantor serta fasilitas kantor yang ada seharusnya dapat memberikan kenyamanan bagi pegawai agar pegawai dapat bekerja dengan baik, leluasa dan bebas untuk bergerak sehingga tercapai efisiensi kerja.
Sukoco (2007:189) menyatakan bahwa "tujuan penataan layout kantor selain memperlancar pekerjaan juga menciptakan rasa nyaman, aman bagi pegawai, memberikan kesan baik kepada tamu, dan mencegah efisiensi tenaga dan waktu pegawai bekerja". Hal ini didukung dengan hasil penelitian Rabbani dan Arifin (2018) bahwa tata ruang kantor berpengaruh positif dan signifikan terhadap kinerja karyawan di instansi tersebut.

\section{SIMPULAN}

Simpulan dalam penelitian ini yaitu (1) Terdapat pengaruh gaya kepemimpinan, pemanfaatan teknologi informasi, dan tata ruang kantor secara simultan terhadap kinerja perangkat desa Se-Kecamatan Suradadi Kabupaten Tegal, (2) terdapat pengaruh parsial gaya kepemimpinan terhadap kinerja perangkat desa Se-Kecamatan Suradadi Kabupaten Tegal, (3) terdapat pengaruh parsial pemanfaatan teknologi informasi terhadap kinerja perangkat desa Se-Kecamatan Suradadi Kabupaten Tegal. (4) Terdapat pengaruh parsial tata ruang kantor terhadap kinerja perangkat desa Se-Kecamatan Suradadi Kabupaten Tegal.

\section{DAFTAR PUSTAKA}

Anasari, R. E., \& Suryani, N. (2015). Pengaruh Kepemimpinan, Lingkungan Kerja, dan Fasilitas Kantor Terhadap Kinerja Perangkat Desa di Kecamatan Limpung Kabupaten Batang. Economic Education Analysis Journal, 4 (1), 98-110.

Ardilla, N. D., \& Pramusinto, H. (2015). Pengaruh Kepemimpinan, Komunikasi Internal, dan Motivasi Kerja Terhadap Kinerja Pegawai BP3AKB Provinsi Jawa Tengah. Dinamika Pendidikan, 10 (1), 53-66.

Fitriani, Diana. (2016). Analisis Pengaruh Penggunaan Teknologi Informasi Terhadap Kinerja Karyawan PT. Asuransi Jiwasraya Pontianak. Cogito Smart Journa,. 4(1), 160-170.

Griffin, Ricky W. (1990). Management. Boston: Houghton Mifflin Company.

Erlangga 
Iqbal. (2015). Effect of Leadership Style on Employee Performance. Arabian Journal of Business and Management, Volume 5. Issue 5, 1-6

Kadir, Abdul dan Terra Ch. Triwahyuni. 2005). Pengenalan Teknologi Informasi. Yogyakarta: Andi Offset.

Kartono, Kartini. (2016.). Pemimpin dan Kepemimpinan: Apakah Kepemimpinan Abnormal Itu? Jakarta: PT RajaGrafindo Persada.

Mamik. (2010). Pengaruh Gaya Kepemimpinan, Motivasi Kerja, dan Komitmen Organisasi Terhadap Kinerja Karyawan. Jurnal Majalah Ekonomi, 10 (1), 83-99.

Mangkunegara, Anwar Prabu. (2016). Manajemen Sumber Daya Perusahaan. Bandung: Remaja Rosdakarya.

Muzakki, M. H, dkk. (2016). Pengaruh Penggunaan Teknologi Informasi Terhadap Kinerja Karyawan (Studi Pada Karyawan PT. Telkom Pusat Divisi Regional V Surabaya). Jurnal Administrasi Bisnis, 39 (2), 169-175.

Palupi, S. R., \& Rustiana, A. (2014). Pengaruh Tata Ruang Kantor, Kelengkapan Fasilitas dan Motivasi Kerja Terhadap Kinerja Karyawan di Kantor Kecamatan Se-Kota Administratif Cilacap. Economic Education Analysis Journal, 3(2).

Puspitasari, M., \& Oktarina, N. (2018). Pengaruh Gaya Kepemimpinan, Budaya Organisasi, dan Tata Ruang Kantor Terhadap Kinerja Pegawai. Economic Education Analysis Journal, 7(1).

Rivai, Veithzal. (2006). Kepemimpinan dan Perilaku Organisasi. Jakarta: PT RajaGrafindo Persada.

Sedarmayanti. (2001). Dasar-Dasar Pengetahuan Tentang Manajemen Perkantoran. Bandung: Mandar Maju.
Simarmata, Janner. (2006). Pengenalan Teknologi Komputer dan Informasi. Yogyakarta: Andi Offset.

Sudarmanto. (2009). Kinerja dan Pengembangan Kompetensi SDM. Yogyakarta: Pustaka Pelajar.

Sukoco, Badri Munir. (2007). Manajemen Administrasi Perkantoran Modern. Surabaya: Gelora Aksara Pratama / Erlangga.

Undang-Undang Nomor 32 Tahun 2004 tentang Pemerintahan Daerah pasal 1 ayat (12). diakses dari http://www.dpr.go.id/dokjdih/docum ent/uu/33.pdf, pada tanggal 16 Desember 2018.

Wibowo. (2016). Manajemen Kinerja. Jakarta: Rajawali Pers.

Wirawan. (2009). Evaluasi Kinerja Sumber Daya Manusia. Jakarta: Salemba Empat. 